\title{
Pleistocene terracing phases in the metropolitan area of Bari - AAR dating and deduced uplift rates of the Apulian Foreland
}

\author{
Vincenzo De Santis (1), Giovanni Scardino (1), José E. Ortiz (2), \\ Yolanda Sánchez-Palencia (2) \& Massimo Caldara (1)
}

\author{
(1) Dipartimento di Scienze della Terra e Geoambientali, Via Orabona 4, Università degli Studi di Bari “Aldo Moro”, 70125 Bari, Italy. \\ (2) Biomolecular Stratigraphy Laboratory, Madrid School of Mines, C/Rios Rosas 21, E-28003 Madrid, Spain. \\ Corresponding author e-mail: vincenzo.desantis@uniba.it \\ Document type: Article \\ Manuscript received 14 February 2020; accepted 05 May 2021; published online 11 May 2021; editorial responsibility and handling by F. Strani.
}

\section{ABSTRACT}

We performed detailed geological and geomorphological analyses on a series of marine terraces located around the city of Bari (southern Italy). Absolute dating was obtained by applying amino acid racemisation (AAR) to ostracod valves taken from deposits lying on marine terraces. The combination of literature data, field geological surveys, digital terrain model analysis, and absolute dating allowed us to recognise and map: i) four terrace surfaces bordered by four inner edges which date to MIS 7.5, 7.3, 7.1, and 5.5; and ii) three terraced deposits, which date to MIS 7.5, 7.1, and 5.5. These new data represent the first dated terraced deposits (older than MIS 5) of the coastal stretch of the Apulian foreland between Trani and Taranto. Using inner edges of the terraces as palaeo sea level markers, we calculate the mean uplift rates that characterised this portion of the Apulian foreland from MIS 7.5, 7.3, 7.1, 5.5 to the present day; these rates are $0.28,0.255,0.15$ and $0.01 \mathrm{~mm} / \mathrm{y}$, respectively. These new dated Pleistocene terraced deposits allow to refine the knowledge on the chronology, the spatial extension and rate of the uplift and, in general, on the Pleistocene geodynamics of the Apulian foreland.

KEYWORDS: inner edges, marine terraced deposits, amino acid racemisation, Apulian foreland, MIS 7, MIS 5.5.

\section{INTRODUCTION}

The marine terrace deposits are widespread features detected in the continental margins of the Mediterranean coasts, which can be attributed to the interaction between sea-level oscillations \& vertical land movements (Bloom 1980; Murray-Wallace and Woodroffe, 2014; Grant et al., 2014; Marra et al., 2019). The landforms of marine terraces can be related to marine erosion effects or can consist of shallow water to slightly emerged sediments redistributed by shore erosional and depositional processes (Pirazzoli, 2005; Rovere et al., 2016). The study of these landforms represents a useful tool for the assessment of the past sealevel changes combined with the vertical land movements, in which their current elevations provide an estimation of the uplift or subsidence rates (Ferranti et al., 2006; Caputo et al., 2010; Meschis et al., 2020).

The study area belongs, from a geological point of view, to the Murge highland, located in the central part of the Apulia region (southern Italy). Although the extensive presence of marine terraces, sometimes covered by marine deposits, has been documented throughout the Murge highlands (Ciaranfi et al., 1992), chronological constraints regarding them are very scarce.

In fact, there are many obstacles to the development of a chronology of terrace formation in the area: i) dateable material is rare; ii) outcropping deposits are scarce; iii) the thickness of the deposits is generally very small. As a result, to date, it has been impossible to build a well constrained chronology of the terrace deposits linked to glacio-eustatic oscillations; in other words, so far only very few chronological data are available in the area. For this reason, an in-depth study of the marine terrace deposits was performed in the metropolitan area of Bari and, in order to provide new insights for its morpho-topography and chronology. The main goal of our study was to develop a complete description of the marine terrace deposits preserved in the surrounding of the city of Bari, including the stratigraphy, ages, and palaeoenvironmental description. In particular, we provide new chronological data based on the Amino Acid Racemisation dating method and discuss them together with the previous ages we obtained for the Apulian foreland. Finally, a new assessment of the vertical movements was performed by means of a comparison of terrace positions and refined ages, which showed spatial variations in rates and timing of uplift around the city of Bari and in other sectors of the Apulian foreland.

\section{GEOLOGICAL SETTING AND PREVIOUS RESEARCH}

Murge highland formed as a large Mesozoic carbonate platform and it is made up of a thick sequence of limestones and dolomitic limestones, often karsified, represented by the Calcare di Bari, (CBA; Servizio Geologico d'Italia, 2003) and the Calcare di Altamura (ALT; Azzaroli et al., 1968b; Servizio Geologico d'Italia, 1968).

Its morphostructural features derive by regional tectonics: a main system of NW-SE oriented normal faults dissects the highland; as a result of a differential uplift, the highland is gently sloping towards the Adriatic Sea, with a sequence of terraces and scarps; instead, toward the Bradanic Trough, the highland is steeply sloping. 
From a geodynamical point of view, this territory belongs to the Apulian foreland, formed during the Neogene in front of the Apennine chain (Fig. 1). In particular, two geodynamic phases affected the Apulian foreland during the Plio-Pleistocene (Ricchetti et al., 1992). In the first phase, the westernmost sectors of the Apulian Foreland underwent strong subsidence (Doglioni et al., 1994) because of active subduction under the Apennine chain. Thus, wide sectors of the foreland evolved into a foredeep (Bradanic Trough). In this context, a Bradanic Trough sedimentary cycle (Ricchetti et al., 1992; Tropeano et al., 2002) began to accumulate with coastal deposits belonging to the Calcarenite di Gravina unit (GRA, Azzaroli, 1968; Iannone \& Pieri, 1979), and culminated in the silty clayey hemipelagic deposits belonging to the Argille subappennine (ASP; Azzaroli et al., 1968a). In the second geodynamic phase (from the middle Pleistocene), the entire Apulian Foreland and Bradanic Trough were uplifted (Ricchetti et al., 1992; Doglioni et al., 1994, 1996): the regressive deposits of the Bradanic Trough cycle and/ or the marine and continental terraced deposits testify this process (Ciaranfi et al., 1992). Global scale glacio-eustatic sea level oscillations occurred together with this regional uplift, which complicated the mechanism of regression. The glacio-eustatic oscillations have also contributed to the deepening of the karst valleys (locally called lame) that characterise the Murgian karst plateau and of the incised valleys recognised on the Apulian continental shelf (De Santis \& Caldara, 2016; De Santis et al., 2020a, 2020b; Valenzano et al., 2018).

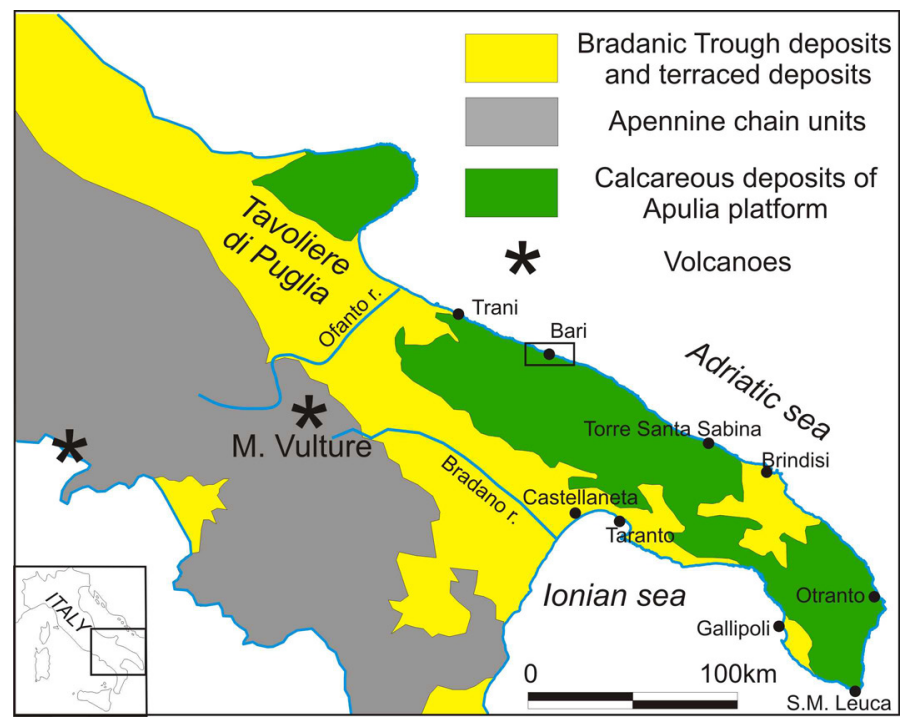

Fig. 1 - Simplified geological sketch of the Apulia region with main geological domains of the southern Italy and location of the study area.

Regarding the Quaternary terraced marine deposits in the Apulia region, the most numerous and chronologically constrained data are only those relating to Tavoliere di Puglia plain (De Santis et al., 2010, 2013, 2014a), to Trani cliff (Caldara et al., 2013; De Santis et al., 2014b), and to Apulian Ionian coast between Taranto and the border with
Basilicata region, at the Bradano River's mouth (Brückner, 1980; Boenzi et al., 1986; Zander et al., 2006; Amorosi et al., 2014; De Santis et al., 2018, 2020c). Caldara et al. (2013) and De Santis et al. (2014b) described, at the Trani cliff, some Quaternary units, named by authors unit I, unit II, and unit III. Unit I was dated to MIS 9 and is characterised by the widespread presence of stromatolites. In particular, the stromatolites of unit I are similar in type, shape and sedimentary environment to the modern stromatolites in Shark Bay (Australia). The water temperature and salinity conditions under which the current stromatolites live indicate that tropical/subtropical conditions were present in the Mediterranean Sea during MIS 9. The numerical ages of units II and III do not clearly permit to distinguish the stages of sedimentation of the two units. Both units relate to a timespan ranging from MIS 8.5 to MIS 7.1.

Along the coastal area from Taranto to the Bradano River, De Santis et al. $(2018,2020$ c) recognised and mapped three terraced deposits that date to MIS 7.3, MIS 7.1, and MIS 5; Boenzi et al. (1986) recognised MIS 5.5 deposits with Thetystrombus latus (sin.: Strombus bubonius) near Castellaneta locality.

Specific researches on describing the terraced deposits present in the Apulian coasts between Trani and Taranto (Fig. 1), where Bari town fall, are very scarce. Although several Quaternary terraced deposits have been recognised in this long stretch of coast (Ciaranfi et al., 1992; Mastronuzzi et al., 2011), no precise chronological constraints have been obtained so far, with few exceptions.

The few data available along the Adriatic coast are rare and mostly poorly constrained and refer exclusively to marine terraces attributed to MIS 5.5. One indirect age constrain is available at Santa Sabina locality, ca. $24 \mathrm{~km}$ north of Brindisi, where a coastal deposit at about $3 \mathrm{~m}$ a.s.l. overlies a colluvial deposit bearing Late PalaeolithicMousterian flints and, thus, could be of MIS 5.5 age (Mastronuzzi \& Sansò, 2003). Geochronological data constrained the occurrence of MIS 5 between Capo Santa Maria di Leuca and Otranto at about $6 \mathrm{~m}$ a.s.l. (Ferranti et al., 2006; Mastronuzzi et al., 2007; Sansò et al., 2015).

Along the Ionian coast between Taranto and Santa Maria di Leuca, the chronological constraints are more present, but always exclusively regarding the MIS 5.5: deposits with $T$. latus have been recognised between Taranto and Gallipoli ranging from 12 to $0 \mathrm{~m}$ a.s.l. (Hearty \& Dai Pra, 1992; Belluomini et al., 2002, Caldara et al., 2003; Amorosi et al., 2014; Negri et al., 2015).

Specifically, for the area of city of Bari and its surrounding, Pieri (1975) was the first to describe, in detail, the outcropping units in the urban area of the city that lie in transgression above CBA and/or GRA. He described, from the earliest to the most recent, the following informal units: 1) brackish deposits; 2) bioclastic deposits II; 3) littoral ridge-bioclastic detrital deposits (two coeval units); 4) dune deposits. In particular, the informal unit 3 was related to the elongated discontinuous ridge that crosses, roughly in $\mathrm{W}$-E direction, the city of Bari. In the absence of absolute dating, the author attributed these units to a generic Pleistocene; for the three most recent units, the author went so far as to hypothesize the attribution to a "generic Tyrrhenian" (MIS 5).

A recent impulse came from the realization of the new geological sheet at 1: 50,000 scale, n. 438 "Bari" in the frame of the CARG Project (Pieri et al., 2011; Servizio 
Geologico d'Italia, 2011); the use of the UnconformityBounded Stratigraphic Units (UBSU; Salvador, 1987, 1994), accepted by the Italian Geological Survey, implied the identification of synthems, which include continental terraced deposits, marine terraced deposits, or both. Thus, the authors recognised and described, among other, the following synthems outcropping in the town of Bari and its surroundings. The synthems represent many Quaternary terraced deposits, have a thickness less than $10 \mathrm{~m}$ and unconformably lie on CBA and/or GRA.

1) Carbonara Synthem (MUB). Silts and fine-grained sands, with calcarenitic pebbles in the lower part, rich in ostracods and fragments of characeans, alternating with mudstones with small gastropods, bivalves, and rare benthic foraminifers (rotalids). In the middle part the synthem is made up of biopeloidal mudstones/wackestones, with micritic intraclasts, benthic foraminifers and rare bioclastic fragments. In the upper part thin beds of calcareous fossiliferous sands alternate with some centimetres thick bioclastic floatstones/rudstones containing benthic foraminifers, brachiopods, echinoids, and gastropods. Thickness: up to $10 \mathrm{~m}$. Palaeoenvironmental interpretation: from lagoon to offshore. Age: Middle-Late Pleistocene?

2) San Pasquale Synthem (MUQ). Well-laminated silts with ostracodes and characean fragments with intercalations of thin bedded nodular limestones showing wackestone texture and fossils (ostracodes, characean oogons and small gastropods) passing upward to well-sorted sands showing well-rounded granules. Calcareous gravels erosionally lie either on the sands or on the silts. Thickness: about 5-6 m. Palaeoenvironmental interpretation: from backshore to foreshore. Age: Late Pleistocene.

3) San Girolamo Synthem (MUI). Well cemented and very porous calcarenites showing small-scale cross lamination, unconformably lying on CBA and GRA. Helix sp. is the only macrofossil found in this unit. Thickness: about $6 \mathrm{~m}$. Palaeoenvironmental interpretation: backshore. Age: Late Pleistocene.

\section{METHODS}

The research methods consisted first in collecting all previous relevant geomorphological literature and reviewing published maps of the marine terraces and their deposits (Servizio Geologico d'Italia, 2011). Then, we carried out a geomorphological analysis by using a $2 \times 2$ and 1x1 m cell width high resolution Digital Terrain Model (DTM) extracted by high-resolution Light Detection and Ranging (LiDAR) provided by "Ministero dell'Ambiente e della Tutela del Territorio e del Mare".

Field mapping analyses along with DTM analyses allowed us to recognize (Fig. 2): i) prominent breaks of slope defining inner edges; ii) terraced surfaces and deposits.

There is general agreement that marine terraces are generated mainly during sea-level highstands and that their inner edges, which are located at the foot of the slope along the inland border of the terrace, represent a palaeoshoreline and indicate the maximum sea level during the highstand (Brückner, 1983; Lajoie, 1986; Ferranti et al. 2006). In hard rock, the inner edge appears as a step between the former wave-cut platform and cliff. In soft rock, it is covered by colluvial deposits and can hardly be identified, because often consists simply in a knickpoint in the topographic profile (De Santis et al., 2020c). In our case, also in consideration of the small thicknesses of colluvial deposits and soils verified during the field survey, we have neglected it.

Dating was performed by applying amino acid racemisation (AAR) to ostracod valves (Cyprideis torosa) following the methods applied in our previous work on marine and alluvial terraced deposits in the Apulia Region (De Santis et al., 2010, 2013; Caldara et al., 2013; De Santis et al., 2014a, b). For this purpose, 64 analytical samples (tab.1, $3^{\text {rd }}$ column) from 13 beds (tab. 1, $1^{\text {st }}$ column) at 4 localities (tab. 1, $2^{\text {nd }}$ column) were analysed in the Biomolecular Stratigraphy Laboratory of the Polytechnical University of Madrid.

Following the preparation protocol described by De Santis et al. (2010; 2013), a certain number of translucent ostracod valves were selected from each bed (analytical samples); then, $\mathrm{D} / \mathrm{L}$ ratio, that is, the ratio between the dextrogyre and levogyre form, were calculated for aspartic acid (Asp) and glutamic acid (Glu) of valves. For the dating of the ostracod samples, we applied the age calculation algorithms developed by Ortiz et al. (2004), which is based on the concept that the $\mathrm{D} / \mathrm{L}$ ratio of amino acids changes as a function of time. The age of a single bed was the average of the numerical ages obtained for the Asp and Glu D/L values measured in their analytical samples.

For the vertical movement assessment, we compute the uplift of dated terraced deposits by adding to their present elevation the palaeo sea-level position of related highstands from the sea level curve of Grant et al. (2014). This curve, like all sea level curves, presents uncertainties: the reported uncertainty on the sea level is $\pm 12 \mathrm{~m}$. In any case, we have referred to the probability maximum for the Relative Sea Level (RSL) data (Grant et al. 2014, Supplementary Data 1). Only for the MIS 5.5 highstand, we did not refer exclusively to the sea level curve of Grant et al. (2014), but also to some specific studies conducted on the eustatic oscillations during that stage (Schellmann \& Radtke, 2004; Coyne et al., 2007; Dutton et al 2015 and references therein). Grant et al. (2012; 2014) defined the Relative Sea-Level (RSL) during the last interglacial (MIS $5.5)$ at $126-130$ or $120-133 \mathrm{ky}$ BP (95\% confidence limits to the maximum-probability RSL (RSL Pmax) and RSL data points, respectively), peaked at about $6 \mathrm{~m}$ at $127-$ 129 or 126-132 ky BP (RSL Pmax and RSL data points, respectively).

\section{RESULTS}

\section{INNER EDGES AND TERRACED SURFACES}

Our mapping identified four inner edges of as many terraces, three of which characterised by the presence of discontinuous terraced deposits (Fig. 2). From the higher to the lower, they are:

i. inner edge 1; its height ranges from ca. $+45 \mathrm{~m}$ a.s.l. in the eastern sector, to ca. $+58 \mathrm{~m}$ a. s. 1 . in the central sector, to ca. $+53 \mathrm{~m}$ a.s.l. in the western sector (Figs. 2 and 3). This inner edge delimits the terraced surface 1. On this terraced surface the Carbonara synthem (Pieri et al., 2011) lies. 
TABLE 1

List of the sampled beds, outcrop localities, number of analytical samples for each bed, biochemical parameters (D/L

Asp, D/L Glu) and related absolute ages. Aspartic acid (Asp) and glutamic acid (Glu) D/L values refer to sampled ostracod valves from the beds. For the provenance of the samples, see the Fig. 2 and stratigraphic sections (Figs. 4-6).

The reader is referred to the text for details on the analytical method.

\begin{tabular}{|c|c|c|c|c|c|c|}
\hline Bed & Locality & $\begin{array}{l}\text { Analytical } \\
\text { samples }\end{array}$ & D/L Asp & D/L Glu & Age (ky) & $\begin{array}{c}\text { Coordinates } \\
\text { (WGS_1984_UTM } \\
\text { Zone_33N }\end{array}$ \\
\hline TB12/4 & $\begin{array}{c}\text { Parco verde } 3 \text { San } \\
\text { Girolamo }\end{array}$ & 5 & $0.365 \pm 0.020$ & $0.128 \pm 0.020$ & $126.0 \pm 24.3$ & $\begin{array}{c}\text { E } 652.542 \\
\text { N } 4.555 .556\end{array}$ \\
\hline $\mathrm{TB} 2 / 1$ & Carbonara-via Fanelli & 5 & $0.434 \pm 0.00$ & $0.189 \pm 0.040$ & $199.2 \pm 39.3$ & $\begin{array}{c}\text { E } 658.001 \\
\text { N } 4.549 .842\end{array}$ \\
\hline $\mathrm{TB} 2 / 2$ & Carbonara-via Fanelli & 5 & $0.452 \pm 0.00$ & $0.167 \pm 0.018$ & $196.6 \pm 38.2$ & $\begin{array}{c}\text { E } 658.001 \\
\text { N } 4.549 .842\end{array}$ \\
\hline $\mathrm{TB} 2 / 3$ & Carbonara-via Fanelli & 5 & $0.434 \pm 0.00$ & $0.216 \pm 0.031$ & $216.9 \pm 37.8$ & $\begin{array}{c}\text { E } 657.958 \\
\text { N } 4.549 .751\end{array}$ \\
\hline $\mathrm{TB} 3 / 1$ & Carbonara-via Fanelli & 5 & $0.453 \pm 0.00$ & $0.188 \pm 0.033$ & $211.8 \pm 45.9$ & $\begin{array}{l}\text { E } 657.958 \\
\text { N } 4.549 .751\end{array}$ \\
\hline $\mathrm{TB} 3 / 2$ & Carbonara-via Fanelli & 4 & $0.422 \pm 0.015$ & $0.176 \pm 0.035$ & $186.3 \pm 25.7$ & $\begin{array}{c}\text { E } 657.958 \\
\text { N } 4.549 .751\end{array}$ \\
\hline TB19/5 & Asclepios III & 5 & $0.416 \pm 0.046$ & $0.192 \pm 0.043$ & $194 \pm 54$ & $\begin{array}{l}\text { E } 656.020 \\
\text { N } 4.553 .107\end{array}$ \\
\hline TB19/6 & Asclepios III & 5 & $0.388 \pm 0.00$ & $0.201 \pm 0.000$ & $186 \pm 28$ & $\begin{array}{c}\text { E } 656.020 \\
\text { N } 4.553 .107\end{array}$ \\
\hline TB20/3 & $\begin{array}{l}\text { Abandoned railway- } \\
\text { villa Romanazzi } \\
\text { Carducci }\end{array}$ & 5 & $0.425 \pm 0.024$ & $0.216 \pm 0.006$ & $214 \pm 20$ & $\begin{array}{l}\text { E } 655.959 \\
\text { N } 4.553 .175\end{array}$ \\
\hline TB20/4 & $\begin{array}{l}\text { Abandoned railway- } \\
\text { villa Romanazzi } \\
\text { Carducci }\end{array}$ & 5 & $0.378 \pm 0.016$ & $0.222 \pm 0.049$ & $195 \pm 56$ & $\begin{array}{l}\text { E } 655.959 \\
\text { N } 4.553 .175\end{array}$ \\
\hline TB20/5 & $\begin{array}{l}\text { Abandoned railway- } \\
\text { villa Romanazzi } \\
\text { Carducci }\end{array}$ & 5 & $0.353 \pm 0.019$ & $0.161 \pm 0.019$ & $142 \pm 22$ & $\begin{array}{l}\text { E } 655.959 \\
\text { N } 4.553 .175\end{array}$ \\
\hline TB21/2 & $\begin{array}{l}\text { Abandoned railway- } \\
\text { villa Romanazzi } \\
\text { Carducci }\end{array}$ & 5 & $0.485 \pm 0.016$ & $0.197 \pm 0.019$ & $239 \pm 31$ & $\begin{array}{l}\text { E } 656.046 \\
\text { N } 4.553 .273\end{array}$ \\
\hline TB21/3 & $\begin{array}{l}\text { Abandoned railway- } \\
\text { villa Romanazzi } \\
\text { Carducci }\end{array}$ & 5 & $0.447 \pm 0.017$ & $0.183 \pm 0.031$ & $206 \pm 33$ & $\begin{array}{l}\text { E } 656.046 \\
\text { N } 4.553 .273\end{array}$ \\
\hline
\end{tabular}

ii. inner edge 2; its height ranges from ca. $+30 \mathrm{~m}$ a.s.l. in the eastern sector, to ca. $+29 \mathrm{~m}$ a.s.l. in the central sector, to ca. $+23 \mathrm{~m}$ a.s.l. in the western sector (figs. 2 and 3). This inner edge delimits the terraced surface 2. On this terraced surface no deposits have been found.

iii. Inner edge 3; its height rests at ca. $+15 \mathrm{~m}$ a.s.l. in the eastern and central sectors, while it is not distinguishable in the western sector (Figs. 2 and 3). On this terraced surface the San Pasquale synthem (Pieri et al., 2011) lies.

iv. inner edge 4 ; its height ranges from ca. $+6 \mathrm{~m}$ a.s.l. in the eastern sector, to ca. $+7.5 \mathrm{~m}$ a.s.l. in the central sector, to ca. $+7 \mathrm{~m}$ a.s.l. in the western sector (Figs. 2 and 3). This inner edge delimits the terraced surface 3. On this terraced surface the San Girolamo synthem (Pieri et al., 2011) lies.

\section{TERRACED DEPOSITS}

\section{TB1 to TB4 Carbonara-via Fanelli}

These stratigraphic sections (Fig. 4) are exposed south of the city of Bari, near Fanelli road, in an area between the southern outskirts of the city of Bari, the Carbonara suburban neighborhood and the municipality of Valenzano; all the outcrops consist of artificial sections or foundation excavations. According to Pieri et al. (2011) and Servizio Geologico d'Italia (2011), these stratigraphic sections fall within the outcropping area of Carbonara synthem.

In the TB1(E 658.499; $\mathrm{N}$ 4.549.086) and TB4 (E 658.125; $\mathrm{N}$ 4.549.371) sections, the terraced deposits unconformably lie on the GRA; the base is characterised 


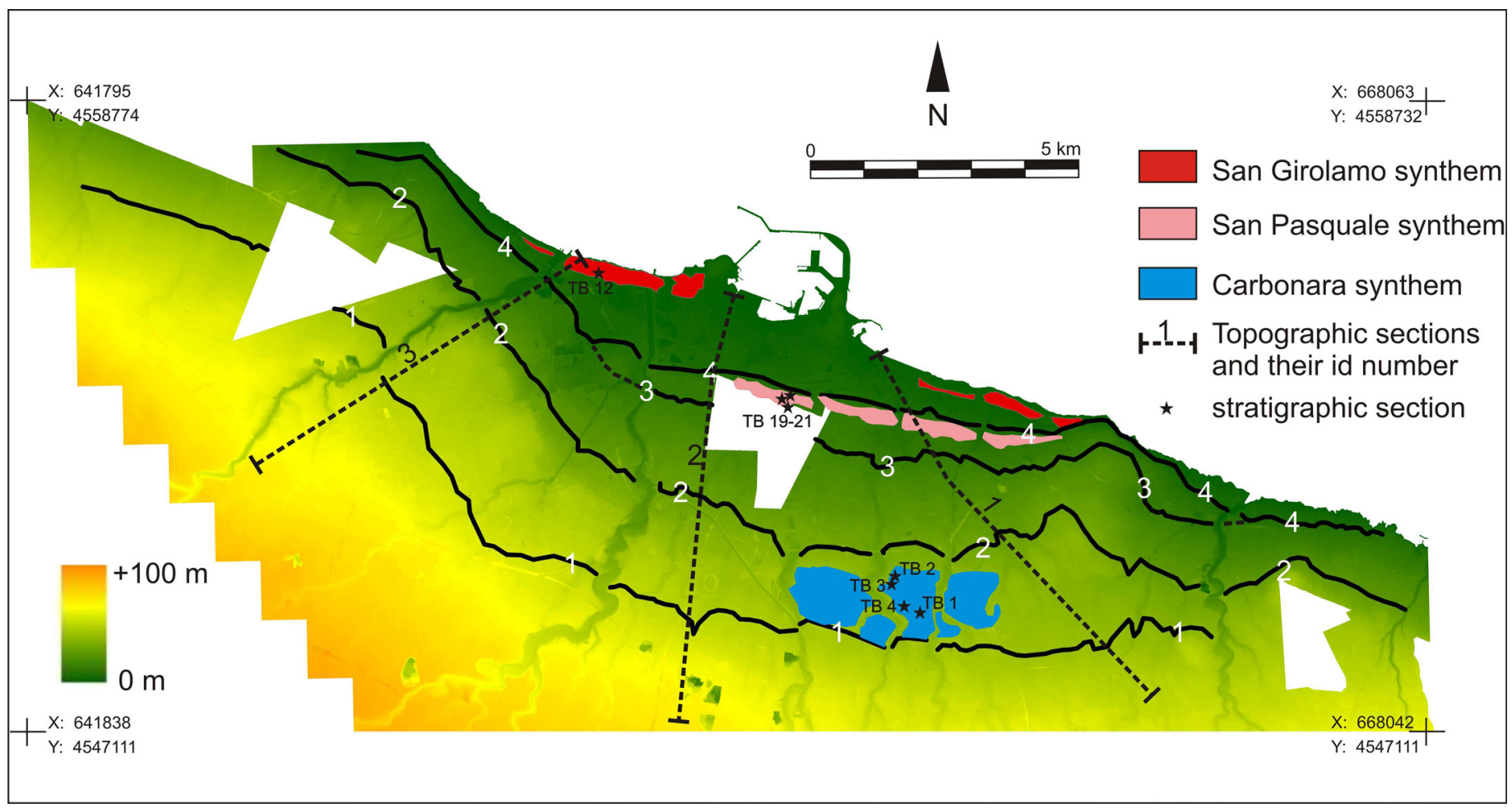

Fig. 2 - Digital Terrain Model (DTM) of the metropolitan area of Bari. Inner edges (continuous black lines) with their identification numbers (in white), terraced deposits (synthems; Servizio Geologico d'Italia, 2011), stratigraphic section studied, and the three topographic sections of Fig. 3 are depicted. The blank areas are not covered by the airborne LiDAR.

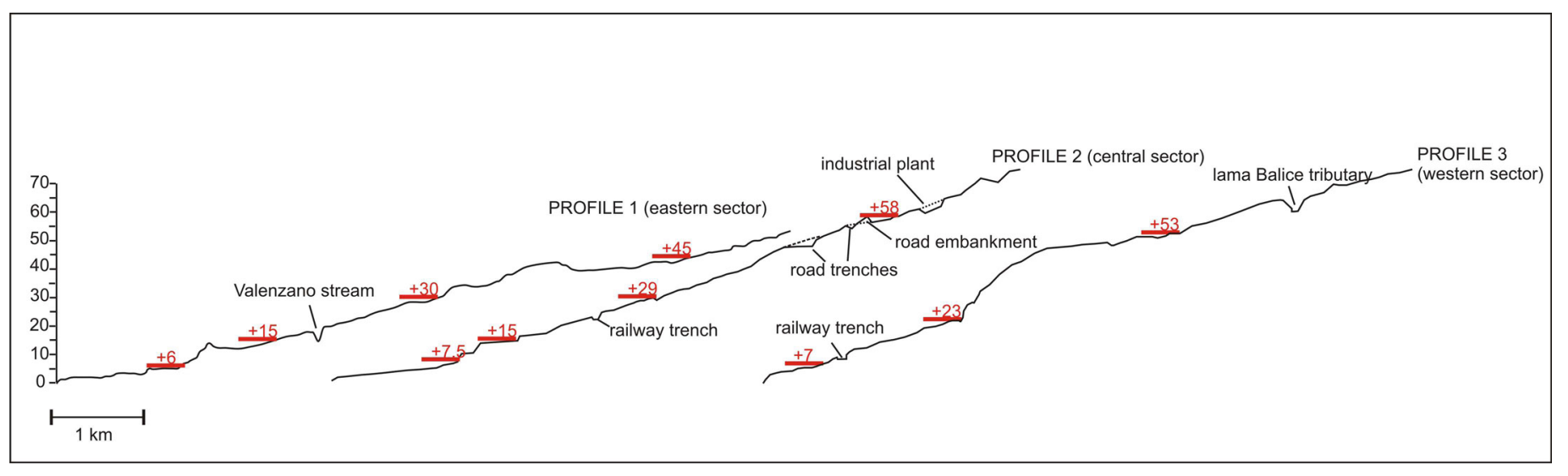

Fig. 3 - Topographic sections of the study area. In red inner edges and their elevation above present sea level are depicted.

by some erosional pockets scoured into the GRA and filled by coarse sand and gravel; most of deposits instead is mainly silty with lenses of coarse beige calcareous sands and/or gravels made up of bioclasts, limestone fragments, calcareous algae fragments. Upwards, coarse sands and/or gravels alternate with thin levels of fine silty sand passing gradually into tawny silt. The macrofauna is represented by Ostrea sp., Chlamys varia, Chlamys sp., gastropods, bryozoans, trochidae, echinoids. The microfauna is represented by ostracods and benthic foraminifera.

In the TB2 (E 658.001; N 4.549.842 and TB3 (E 657.958; $\mathrm{N}$ 4.549.751) sections, the substrate does not crop out; in both outcrops the terrace deposit is made up of grey fine sediments, from clay to silt, with caliche nodules, sometime with cemented layers. The macrofauna is represented by a rich assemblage of Cerastoderma glaucum, Abra segmentum, Hydrobiidae, Teodoxus fluviatilis, Mytilaster sp., Balanus sp., Characeae fragments. The microfauna is represented by ostracods (mainly Cyprideis torosa) and Ammonia sp.

The group of Carbonara-via Fanelli sections shows deposits from marine environment, probably infralittoral (TB1, TB4), to lagoonal (TB2, TB3) with a faunal association representative of the euryhaline and eurytherm lagoon biocoenosis (LEE sensu Pérès, 1967). Based on AAR dating of the ostracod valves, these sections yielded, on the whole, ages between a minimum of $186.3 \pm 25.7 \mathrm{ky}$ and a maximum of $216.9 \pm 37.8 \mathrm{ky}$ (tab.1). 


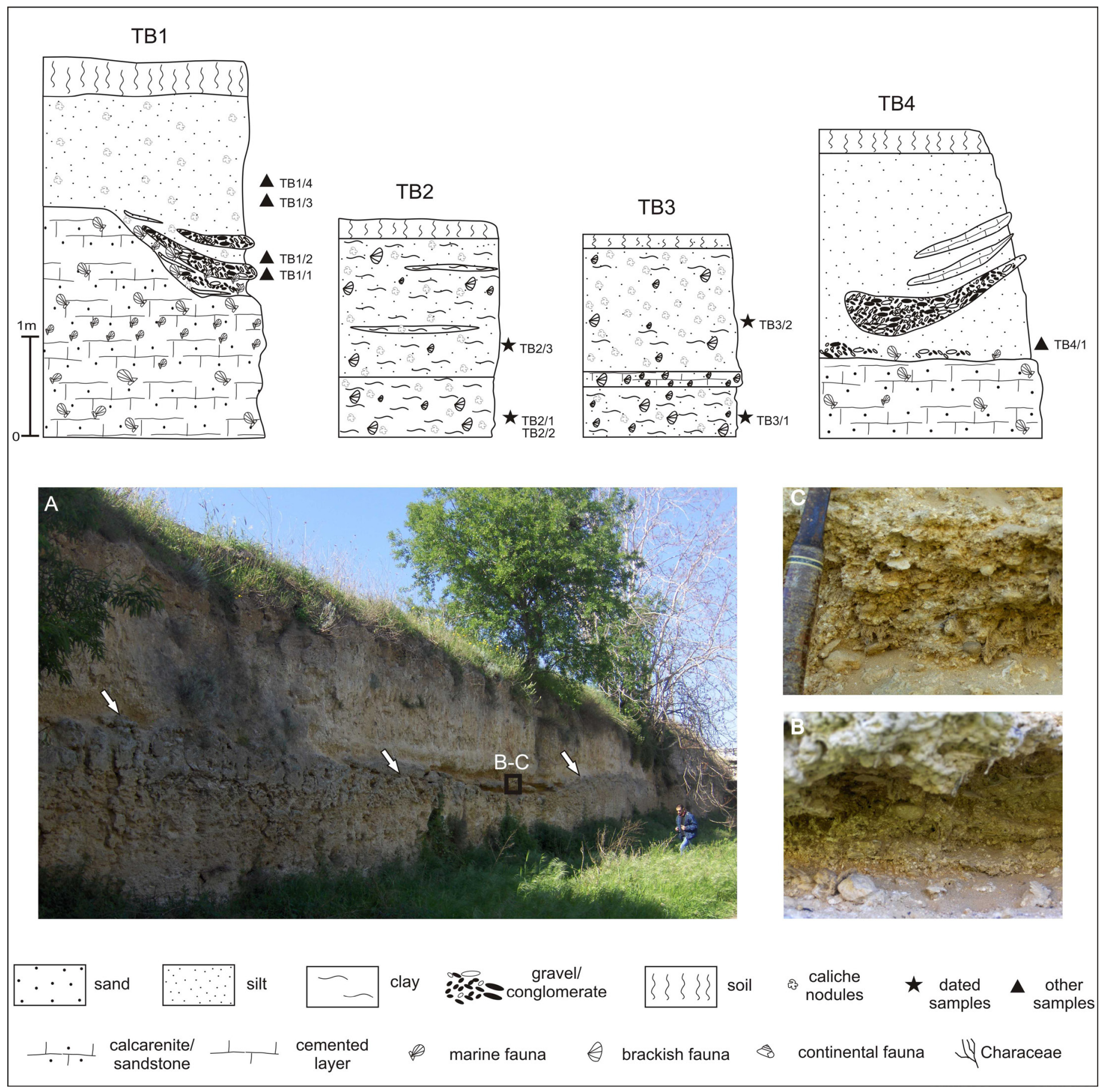

Fig. 4 - Stratigraphic sections TB1 to TB4, where the Carbonara synthem crops out. The legend is also valid for Figs. 5 and 6 . Below: photo of the TB1 section (A); arrows show the erosive contact between the substrate (Calcarenite di Gravina, GRA) and the Carbonara synthem, with close up of the coarse-grained sediment at the base of the Carbonara synthem (B, C).

TB19 to TB21 Asclepios III-abandoned railway-villa Romanazzi Carducci

These stratigraphic sections (Fig. 5) are exposed within the city of Bari. TB19 (E 656.020; N 4.553.107) consists in an excavation for the foundation of a new hospital pavilion (Asclepios III) within the Polyclinic of Bari, while the nearby TB20 (E 655.959; $\mathrm{N}$ 4.553.175) and TB21 (E 656.046; N 4.553.273) are artificial walls that delimit an abandoned section of a railway, between Villa Romanazzi Carducci Hotel and the Music Conservatory. The section TB21 had already been described by Pieri (1975) and Pieri et al (2011).

All these three outcrops consist of artificial sections and fall within the outcropping area of San Pasquale synthem according to Pieri et al. (2011) and Servizio Geologico d'Italia (2011).

Overall, these three close outcrops, together with other small outcrops in the vicinity, allow us to reconstruct the following stratigraphic succession. 
The lower unit, from a few decimeters to ca. $2 \mathrm{~m}$ thick, is made up of laminated silts rich in Hydrobiidae and Helicidae and small gastropods; among the microfauna, ostracods and remains of Characeae are abundant, to which Elphidium spp. and Ammonia spp. are added. Towards the top, the silty unit passes continuously and rapidly to the sandy unit, $1.5-2 \mathrm{~m}$ thick; this unit is made up of well-classed sands, with rounded granules, lacking in matrix and with a great abundance of ferro-magnesian minerals likely sourced by the Vulture volcano, brought to the Adriatic Sea by the Ofanto river and carried by the littoral drift which, although over time has undergone reversals (De Santis \& Caldara, 2015), at the time of the deposition of the San Pasquale synthem, moved from NW to SE along the Adriatic coast of Apulia, similar to what happens today.

The sandy unit shows subparallel layers, with a weak landward inclination. Both the silty unit and the sandy unit are affected for almost their entire thickness by softsediment deformation structures such as load-casts and ball and pillows, with irregular shapes, often subspherical (Moretti \& Tropeano, 1996; Moretti et al. 2016). In addition, at the interface between the two units, there are nodules of whitish calcareous crust. More seaward from previously described sections, near Music Conservatory of Bari (E 655.949; N 4.553.312), a gravelly-sandy deposit, about one
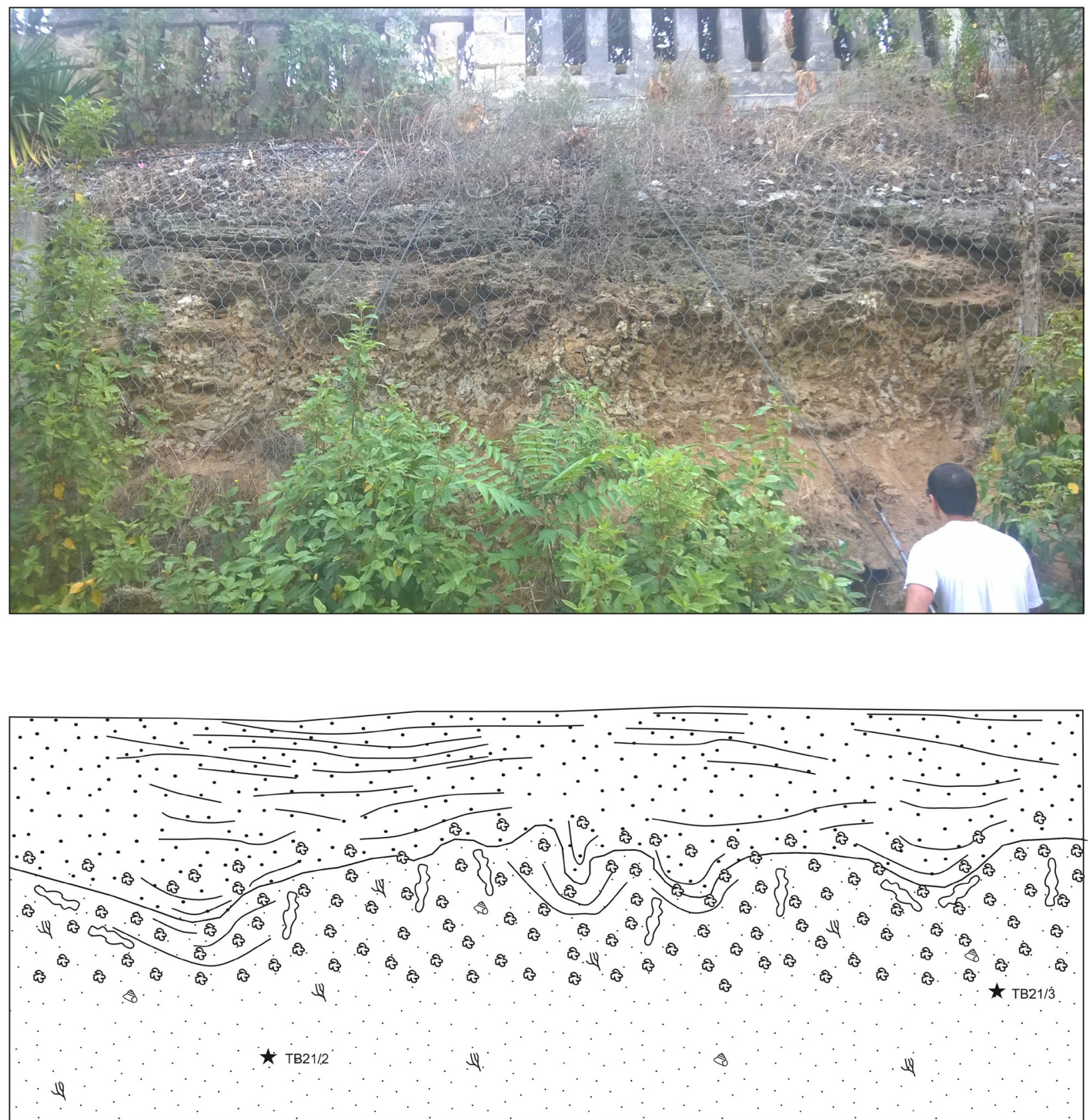

Fig. 5 - Photo and stratigraphic section of TB21, where San Pasquale synthem crops out. 
metre thick, lies in erosive contact above the sandy unit; the erosion surface is inclined towards the sea and cuts the underlying sediments up to the Cretaceous substrate. The gravel layers are made up of well-rounded discoidal limestone pebbles.

From an environmental point of view, the silty deposit is referable to a lagoon environment. The overlying sandy unit is attributable to aeolian deposition, in accordance with what has already been reported in Pieri et al. (2011). The overlapping aeolian sands on the lagoon deposits suggest a coastal depositional system migrating landwards. The gravel unit, due to its textural, grain size and geometric characteristics, can be referred to a shore environment.

Based on AAR dating of the ostracod valves, these sections yielded, on the whole, ages between a minimum of $142 \pm 22 \mathrm{ky}$ and a maximum of $239 \pm 31 \mathrm{ky}$ (tab. 1 ).

\section{TB12 Parco verde 3 San Girolamo}

This stratigraphic section (Fig. 6; E 652.542; N 4.555.556) has been measured at a foundation excavation exposed in the San Girolamo district of Bari. According to Pieri et al. (2011) and Servizio Geologico d'Italia (2011), this stratigraphic section falls within the outcropping area of San Girolamo synthem.

The substrate does not crop out; thus, the section shows terrace deposit only. Starting from the bottom and moving up, they are calcareous silts to fine whitish calcareous sands with a cemented layer on the top. The macrofauna is represented by Ditrupa sp., Chlamys varia, Nucula sp., Nuculana commutata, Timoclea ovata, Anomia sp., moulds of indeterminable molluscs, bryozoans, calcareous algae, echinoids fragments. The microfauna is represented by rare ostracods and benthic foraminifera. In abrupt contact with the above-described unit, there is a second unit made up of brownish silts; toward the top, they merge into a brown-reddish palaeosol; the contact between the silts and the soil is marked by a discontinuous cemented layer. The macrofauna is present only in the silts and it consists of Cerastoderma glaucum, moulds of Hydrobiidae, and fragments of Balanus sp. The microfauna is abundant and oligotypic and constituted by ostracods and rare Ammonia sp.

The third unit lies on the palaeosol and consists of mixed calcareous siliciclastic sands, sometimes cemented, with granules frosted and well rounded. The macrofauna is represented only by internal moulds of pulmonate gastropods, while no microfauna is present. Remarkably, the contact surface between the palaeosol and the overlying sands is very undulate, with vertical interdigitations of sands into palaeosol and vice versa.

The Parco Verde 3 section shows deposits from marine environment, probably infralittoral, to lagoonal, to continental. The contact between the palaeosol and the overlaying sands is very undulate and not erosive; rather, it appears due to bioturbations, perhaps by roots. In addition, the grains of the uppermost sandy unit appear frosted and rounded: all these elements led us to conclude that the uppermost unit was formed as a coastal dune deposit, which covered (not erosively) a soil of the retrodunal environment; then, bioturbation occurred that created the interdigitations between the soil and the sands.

Based on AAR dating of the ostracod valves, this section yielded an age of $126 \pm 24.3 \mathrm{ky}$ (Tab. 1 ).

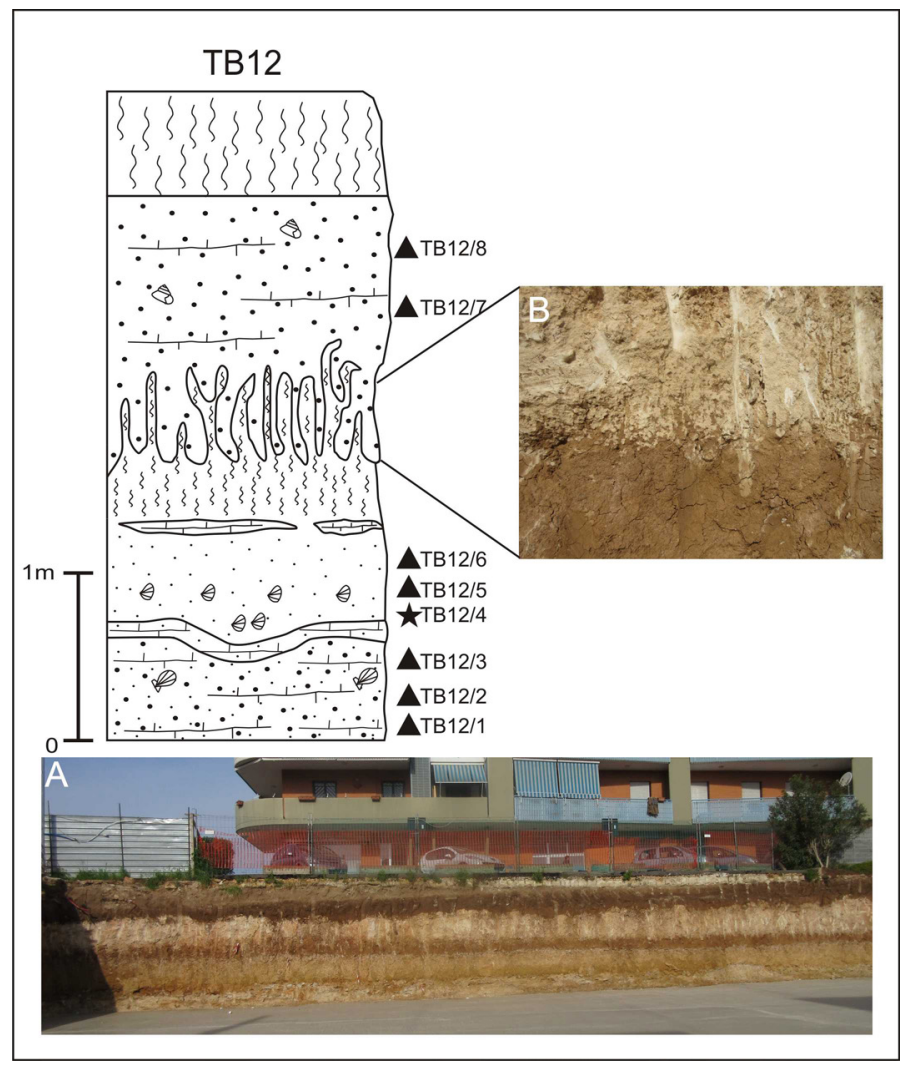

Fig. 6 - Stratigraphic section of TB12, where the San Girolamo synthem crops out. A: photo of the TB12 section showing the different lithological units described; B: close-up of the contact surface between the palaeosol and the overlying sands.

\section{DISCUSSION}

\section{GENERAL FRAMEWORK}

The combination of the field geological survey, DTM analysis, absolute dating and literature data allowed us to recognise four inner edges which border as many terraced surfaces sloping slightly seaward, on which three terraced deposits lie. These latter correspond, from higher to lower to Carbonara, San Pasquale, and San Girolamo synthems (Pieri et al., 2011; Servizio Geologico d'Italia, 2011). Both inner edges and corresponding platforms were incised on a substrate (CBA or GRA) much older than the terracing phase.

The only date obtained for the San Girolamo synthem (Tab. 1) indicates MIS 5.5 (Fig. 7), which we also attribute to both terraced surface 4 and corresponding inner edge 4. The dates obtained for San Pasquale and Carbonara synthems (tab. 1) indicate the range MIS 7.1-7.5 (Fig. 7) but they do not permit to differentiate between the substages of MIS 7; the experience gained with the racemization of amino acids (De Santis et al, 2010, 2013), in fact, shows that, with the AAR dating method, it is necessary to consider the age populations, and no single ages. However, on the basis of their respective elevation above the present sea level, we concluded that: i) Carbonara synthem, terraced surface 1 and inner edge 1 are attributable to MIS 7.5; ii) both terraced surface 2 (lacking in deposits) and corresponding inner edge 2 are attributable to MIS 7.3; iii) San Pasquale synthem, terraced surface 3 and inner edge 3 are attributable to MIS 7.1. 
Two remarkable geomorphological considerations:

i. according to our reconstruction, the terraced surface 1, that hosts the Carbonara synthem (MIS 7.5), appears more raised in central and the western sector of the study area, than the eastern sector (Fig. 3);

ii. the inner edge of the terraced surface 4, that hosts the San Girolamo synthem (MIS 5.5), coincides with the base of the northern slope of the discontinuous ridge stretched in the W-E direction which represents the San Pasquale synthem (Pieri, 1975). In our interpretation, the presence of this ridge, dating back to MIS 7.1, played an active role in determining the local inner limit of the subsequent Tyrrhenian transgression, which formed its inner edge partly eroding the foot of the San Girolamo synthem ridge. This role of the coastal ridges formed during previous highstand in influencing the position of the shorelines of subsequent highstands has already been observed on the Apulian Ionian side between Taranto and the border with Basilicata (De Santis et al., 2020c).

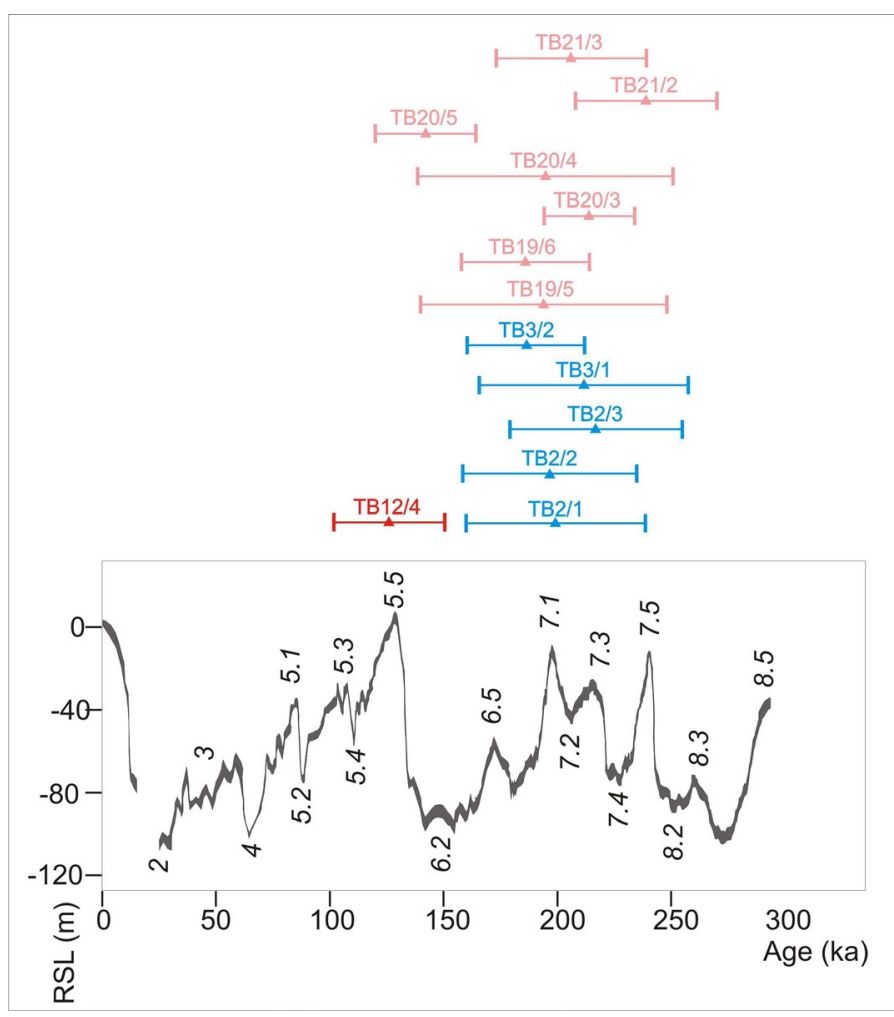

Fig. 7 - Numerical ages obtained with the AAR dating method applied to ostracod valves. Cyan: Carbonara synthem; pink: San Pasquale synthem; red: San Girolamo synthem. Each age reports the mean value and its standard deviation. The ages are plotted on the sea level curve of Grant et al. (2014) (dark grey band: 95\% probability interval for the probability maximum).

\section{VERTICAL MOVEMENTS}

When assessing vertical movements based on marine terraces, the inner edge, which is considered a palaeoshoreline, is generally a crucial element (Lajoie,
1986). The assumption that the inner edge of the terrace coincides with the palaeoshoreline of the highstand that generated the terrace itself becomes more precise when more palaeoshoreline is etched into the substrate on which the deposit lies, instead of simply coinciding with the knickpoint between the upper surface of the terraced deposit and the slope bordering the terrace towards the inland (Carobene, 1980; De Santis et al., 2018). In our case, although the inner edges of all terraces are not etched into the substrate on which the deposit lies, we can easily consider the inner edge as very approaching the palaeoshoreline due to the negligible thickness of the soil coverage.

The palaeoshoreline of inner edge 4, referable to terraced surface 4, which hosts the san Girolamo synthem, dates back to MIS 5.5 highstand. Inner edge 4 extends at an elevation ranging from ca. $+6 \mathrm{~m}$ a.s.l. in the eastern sector, to ca. $+7.5 \mathrm{~m}$ a.s $\mathrm{l}$. in the central sector, to ca. $+7 \mathrm{~m}$ a.s.l. in the western sector (Fig. 3). To calculate the uplift rate, we consider the age of $126 \mathrm{ka} \mathrm{BP}$ (tab.1) for this inner edge. In addition, we consider a MIS 5.5 highstand at ca. $+6 \mathrm{~m}$, because it is the most common value according to a specific literature on the sea level of this stage (Schellmann \& Radtke, 2004; Coyne et al., 2007; Dutton et al., 2015 and references therein). In addition, a sea level peak at $+6 \mathrm{~m}$ during MIS 5.5 is also reported by Grant et al. $(2012 ; 2014)$. Thus, the MIS 5.5 palaeoshoreline would have undergone an uplift ranging between ca. $0 \mathrm{~m}$ in the east sector, $1.5 \mathrm{~m}$ in the central sector and $1 \mathrm{~m}$ in the west sector of the study area. As a consequence, the estimated mean uplift rates between MIS 5.5 and present day are $0 \mathrm{~mm} / \mathrm{y}$ in the eastern sector, and $0.01 \mathrm{~mm} / \mathrm{y}$ in the central and western sectors (Fig. 8). The mean uplift rate for the whole inner edge MIS 5.5 terrace is $0.01 \mathrm{~mm} / \mathrm{y}$, without remarkable differences between the three sectors of the study area.

The palaeoshoreline of inner edge 3, referable to terraced surface 3 which hosts the San Pasquale synthem, dates back to MIS 7.1 highstand. Inner edge 3 rests at a height of ca. $+15 \mathrm{~m}$ a.s.l. in the eastern and central sectors, while it is not distinguishable in the western sector (Figs. 2 and 3). To calculate the uplift rate, we consider the age of this inner edge at ca. $197 \mathrm{ky} \mathrm{BP}$ (Grant et al., 2014). In addition, we assume a 7.1 highstand at ca. -14 (Grant et al., 2014). Thus, the MIS 7.1 palaeoshoreline would have experienced an uplift of ca. $29 \mathrm{~m}$ in the eastern and central sector of the study area, respectively. As a consequence, the estimated mean uplift rate between MIS 7.1 and present day is around ca. $0.15 \mathrm{~mm} / \mathrm{y}$ both in the eastern and central sectors of the study area (Fig. 8).

The palaeoshoreline of inner edge 2, referable to terraced surface 2 which lack of deposits, dates back to MIS 7.3 highstand. Inner edge 2 extends at an elevation ranging from ca. $+30 \mathrm{~m}$ a.s.l. in the eastern sector, to ca. $+29 \mathrm{~m}$ a.s.l. in the central sector, to ca. $+23 \mathrm{~m}$ a.s.l. in the western sector (Fig. 3). To calculate the uplift rate, we consider the age of this inner edge at ca. $215 \mathrm{ky} \mathrm{BP}$ (Grant et al., 2014). In addition, we assume a 7.3 highstand at ca. $-29 \mathrm{~m}$ (Grant et al., 2014). Thus, the MIS 7.3 palaeoshoreline would have experienced an uplift of ca. 59, 58, and $52 \mathrm{~m}$ in the eastern, central, and western sector of the study area, respectively. As a consequence, the estimated mean uplift rates between MIS 7.3 and present day are around ca. $0.27 \mathrm{~mm} / \mathrm{y}$ in the eastern and central sector, and ca. $0.24 \mathrm{~mm} / \mathrm{y}$ in the western sector (Fig. 8). The mean uplift rate for the whole 
inner edge of the MIS 7.3 terrace is $0.255 \mathrm{~mm} / \mathrm{y}$, without remarkable differences between the three sectors of the study area.

The palaeoshoreline of inner edge 1, referable to terraced surface 1, which hosts the Carbonara synthem, dates back to MIS 7.5 highstand. Inner edge 1 extends at an elevation ranging from ca. $+45 \mathrm{~m}$ a.s.l. in the eastern sector, to ca. $+58 \mathrm{~m}$ a. s. 1 . in the central sector, to ca. +53 $\mathrm{m}$ a.s.l. in the western sector (Fig. 3). To calculate the uplift rate, we consider the age of this inner edge at ca. 240 ka BP (Grant et al., 2014). In addition, we assume a 7.5 highstand at ca. $-16 \mathrm{~m}$ (Grant et al., 2014). Thus, the MIS 7.5 palaeoshoreline would have experienced an uplift of ca. 61,74 , and $69 \mathrm{~m}$ in the eastern, central and western sector of the study area, respectively. As a consequence, the estimated mean uplift rates between MIS 7.5 and present day are ca. $0.25,0.31$, and $0.29 \mathrm{~mm} / \mathrm{y}$ in the eastern, central and western sector of the study area, respectively (Fig. 8). The mean uplift rate for the whole inner edge of the MIS 7.5 terrace is $0.28 \mathrm{~mm} / \mathrm{y}$, with a more remarkable difference between eastern and central-western sector.

\section{COMPARISON OF VERTICAL MOVEMENTS AND CONCLUDING REMARKS}

The new chronological constraints presented in this work, which are also the first obtained for the centralsouthern Apulian Adriatic sector, make it possible to update and enrich the framework of the vertical movements of the Apulian foreland in the middle and late Pleistocene. The uplift rates relating to MIS 7 terraces calculated in our previous works result slightly revised on the basis of the
Grant et al. (2014) sea level curve, for consistency with the new uplift rates presented in this article.

In the Apulian sector of Gulf of Taranto (De Santis et al., 2018), mean uplift rates between MIS 5.5 and the present day decrease from ca. 0.39 , to ca. 0.35 , to ca. 0.26 $\mathrm{mm} / \mathrm{y}$ passing from the western, to the central, to the eastern sector, respectively (Fig. 9). The mean uplift rate between MIS 7.1 and the present day has been calculated only for the central sector, resulting in a rate of $0.38 \mathrm{~mm} / \mathrm{y}$ (Fig. 9). The mean uplift rates between MIS 7.3 and the present day decrease from ca. 0.69 , to ca. 0.53 , to ca. 0.43 $\mathrm{mm} / \mathrm{y}$ passing from the western, via the central, to the eastern sector, respectively (Fig. 9).

In the Tavoliere di Puglia plain (De Santis et al., 2010), MIS 5.5 deposits are present below the present sea level in the central coastal stretch of the plain; the calculated subsidence rate, from MIS 5.5 to the present day, is ca. -0.21 $\mathrm{mm} / \mathrm{y}$. Also, some dated layers of MIS 7.1 and MIS 7.3 have been intercepted in two different boreholes in the seaward part of the plain, at $-68 \mathrm{~m}$ (Pt8 borehole) and -32 m (MM4 borehole), respectively. From the data and chronological constraints published in De Santis et al. (2010) and assuming the ages of MIS 7.1 and 7.3 highstands defined by Grant et al. (2014), it is possible to estimate subsidence rates of ca. $0.27 \mathrm{~mm} / \mathrm{y}$ from MIS 7.1 and the present day, and of ca. $0.01 \mathrm{~mm} / \mathrm{y}$ from MIS 7.3 and the present day (Fig. 9). In this case, the high difference in the subsidence is probably due to the fact that the MIS 7.1 dated level in Pt8 borehole and the MIS 7.3 dated level in MM4 borehole are located respectively in the hanging wall and foot wall of a buried normal fault (Caldara et al., in press).

At the Trani cliff (Caldara et al., 2013; De Santis et al., 2014b), units II and III relate to a timespan ranging from

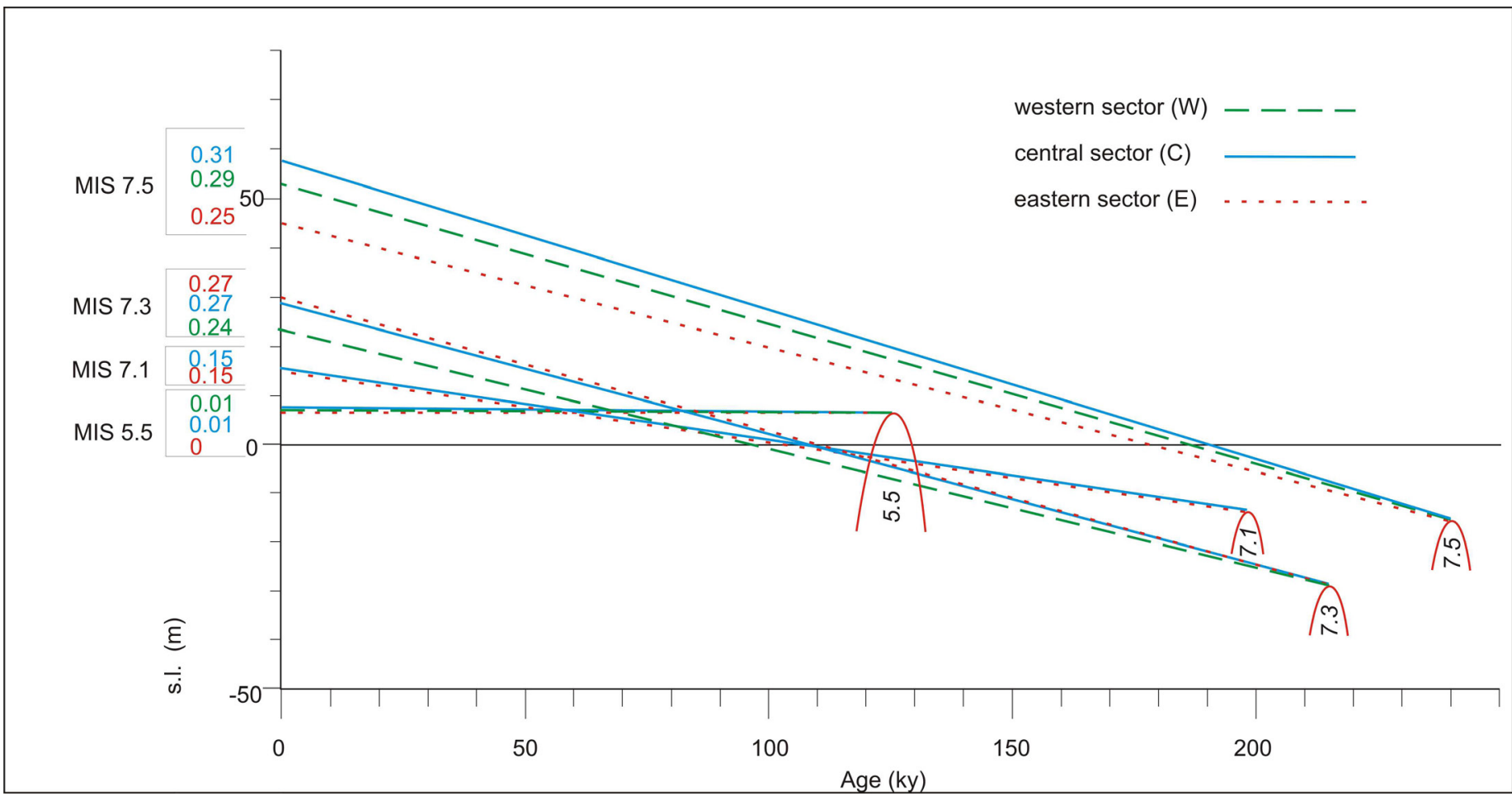

Fig. 8 - Vertical uplift for each inner edge recognised in our study area. Each segment joins the present inner edge elevation (vertical axis) with the highstand of its formation (according to sea level curve of Grant et al. (2014)); for each inner edge the elevations and related uplift rates are reported in the three sectors (red: eastern sector; cyan: central sector; green: western sector). 


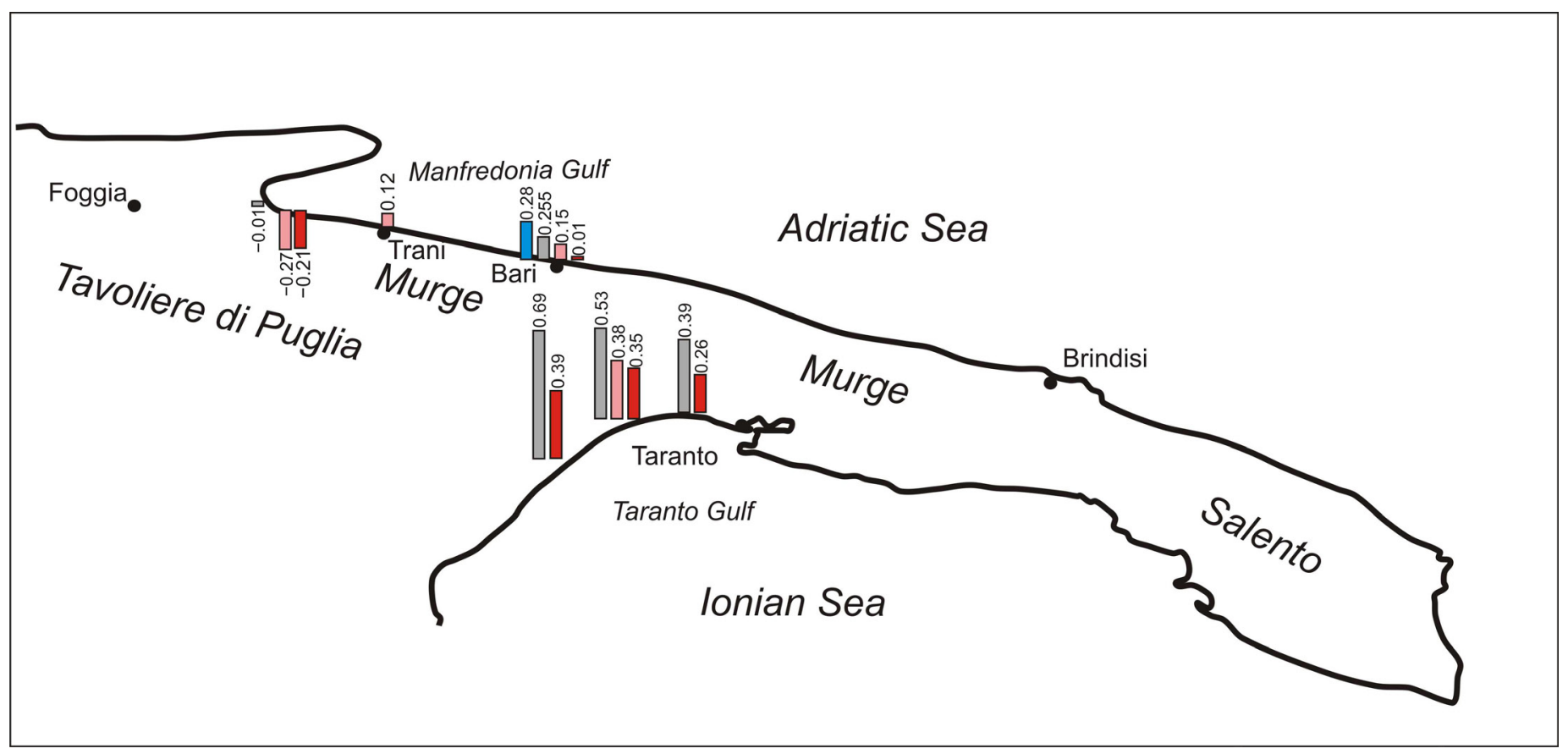

Fig. 9 - Overview of mean uplift/subsidence rates (in $\mathrm{mm} / \mathrm{y}$ ) calculated so far in this and our previous studies for middle-Late Pleistocene marine terraced deposits of the Apulia region; from N to S: Tavoliere di Puglia sites (MM4 borehole, Pt8 borehole, central coastal stretch), Trani cliff, Bari town, Ionian coast between Taranto and the border with Basilicata. Red: MIS 5.5; pink: MIS 7.1; grey: MIS 7.3; cyan: MIS 7.5.

MIS 8.5 to MIS 7.1, while MIS 5 deposits do not crop out, having been completely eroded. The uppermost part of unit III, the highest in the Trani cliff, is made up of lagoonal calcisiltite containing Abra segmentum and Cerastoderma glaucum, whose base today is at ca. $+8 \mathrm{~m}$ a.s.l. Thus, if we assume that this uppermost part dates back to MIS 7.1 and that Cerastoderma glaucum generally lives up to a maximum depth of -2 m (Gravina et al., 1989; Vacchi et al. 2016; Quarta et al. 2019), then a MIS 7.1 highstand at ca. $-14 \mathrm{~m}$ dating back to $197 \mathrm{ka}$ BP (Grant et al., 2014) implies an uplift of ca. $24 \mathrm{~m}$ of the base of uppermost part of unit III, with a mean rate of $0.12 \mathrm{~mm} / \mathrm{y}$ between MIS 7.1 and today (Fig. 9).

Putting together the data collected so far by us on the vertical movements of the Apulian foreland, it results that:

i. the area of the Tavoliere di Puglia plain appears in subsidence throughout the MIS 7 and MIS 5, with increasing rates towards the central part of the coastal strip of the plain (Fig. 9).

ii. the Murge area experienced an uplift for the entire MIS7, with decreasing rates passing from MIS 7.5 to MIS 7.1. This uplift seems to have stopped since MIS5 (Fig. 9). In particular, the data of this work show how, just at the height of the city of Bari, there is an abrupt transition between a domain to the east of the city, characterised by slower uplift rates during MIS 7, and a domain to the west of the city with higher uplift rates, again during MIS 7. The stop of the uplift, starting from MIS 5.5, instead affected both sectors.

iii. The area of the Ionian coast between Taranto and the border with Basilicata appears in constant uplift from MIS 7 onwards, with decreasing rates in space from W to E and over time from MIS 7 to MIS 5.5 (Fig. 9), as already stated by Brückner (1980).
The uplift of the terraces we recognised at the Trani cliff, in the Bari area and Gulf of Taranto occurs at a time when the shortening in the Apennines and the frontal blind thrust had just been de-activated (Cinque et al., 1993; Patacca \& Scandone, 2001, 2004). In fact, this deactivation occurs in the middle Pleistocene at approximately $0.65 \mathrm{Ma}$ (Patacca $\&$ Scandone, 2001, 2004) and falls within the change in the deformation style in the southern Apennine, which has been widely recognised during the middle Pleistocene, from dominantly thrust tectonics to a widespread regional uplift (Bordoni \& Valensise, 1999; Schiattarella et al., 2017).

Thus, the uplift of the terraces reconstructed in this work is related to the more generalised uplift that characterised the chain, foredeep and Apulian foreland starting from middle Pleistocene, the so called Ionian bulge (Ferranti et al., 2006). This large-scale topographic bulge, recorded by uplift and deformation of the MIS 5.5 terrace, is centred in Calabria and NE Sicily, and progressively vanishes towards Apulia region to the north and Hyblean Plateau to the south (Westaway, 1993; Ferranti et al., 2006; Faccenna et al., 2011).

The cause of the Ionian bulge is at present still a matter of debate. One hypothesis suggests that the acceleration of uplift in the Apennines occurred as lithospheric rebound in response to the break-up of the underlying slab (e.g., Cinque et al., 1993; Westaway, 1993). Some authors (e.g., D'Agostino et al., 2001; Lavecchia et al., 2003) suggest that mantle upwelling is occurring under the Apennines belt and that it could be responsible for the observed Quaternary volcanism and coeval occurrence of uplift and crustal extension. Faccenna et al. $(2007,2014)$ infer that a large fraction of the Apennines topography is related to dynamic mantle upwelling, in turn related to the formation and enlargement of a slab windows below the southerncentral Apennines starting in the early Pleistocene. 
Our data do not allow to add anything to the debate on the cause of the Ionian bulge, but allow us to confirm that, whatever the mechanism that triggered the so-called Ionian bulge, it is wearing off, at least in the Apulian foreland.

\section{ACKNOWLEDGMENTS}

We very gratefully acknowledge Helmut Brückner (Universität zu Köln) and Marco Mancini (CNR IGAG) for the careful review of our manuscript.

\section{REFERENCES}

Amorosi A., Antonioli F., Bertini A., Marabini S., Mastronuzzi G., Montagna P., Negri A., Rossi V., Scarponi D., Taviani M., Angeletti L., Piva A. \& Vai G.B. (2014) - The Middle-Upper Pleistocene Fronte Section (Taranto, Italy): An exceptionally preserved marine record of the Last Interglacial. Global and Planetary Change, 119, 23-38.

Azzaroli A. (1968) - Calcarenite di Gravina. Studi illustrativi della Carta Geologica d'Italia - Formazioni Geologiche, Fasc. 1, 183 187.

Azzaroli A., Perno U. \& Radina B. (1968a) - Note illustrative del Foglio 188 "Gravina di Puglia" della Carta Geologica d'Italia alla scala 1:100.000. Servizio Geologico d'Italia, Roma.

Azzaroli A., Radina B., Ricchetti G. \& Valduga A. (1968b) - Note illustrative alla Carta Geologica d'Italia: Foglio 189 "Altamura". pp. 48, Servizio Geologico d'Italia, Roma.

Belluomini G., Caldara M., Casini C., Cerasoli M., Manfra L., Mastronuzzi G., Palmentola G., Sansò P., Tuccimei P. \& Vesica P.L. (2002) - The age of Late Pleistocene shorelines and tectonic activity of Taranto area, Southern Italy. Quaternary Science Reviews, 21, 525-547.

Bloom AL (1980) - Late Quaternary sea level change on South Pacific coasts: a study in tectonic diversity. Earth rheology, isostasy and eustasy, proc symp, Stockholm, 1977, 505-516.

Boenzi F., Caldara M. \& Pennetta L. (1986) - La trasgressione tirreniana nei dintorni di Castellaneta (Taranto) - Geol. Appl. ed Idrogeol., 20(1), 163-175.

Bordoni P. \& Valensise G. (1999) - Deformation of the 125ka marine terrace in Italy: tectonic implications. In: Stewart I.S. \& Vita Finzi C. (eds.), Coastal Tectonics. Geological Society, London, Special Publications, 146, 71-110.

Brückner, H. (1980) - Marine Terrassen in Süditalien. Eine quartärmorphologische Studie über das Küstentiefland von Metapont. - Düsseldorfer Geographische Schriften, 14, 235 p.; Düsseldorf (PhD thesis).

Brückner H. (1983) - Ein Modell zur Genese mariner Akkumulationsterrassen. Essener Geogr. Arb., 6, 161-186.

Caldara M., Capolongo D., Del Gaudio V., De Santis V., de Torres T., Ortiz J.E., Pennetta L., Maiorano P. \& Simone O. (in press) - Note illustrative della Carta Geologica d'Italia alla scala 1:50.000, F. 409 Zapponeta.

Caldara M., Iannone A., Lopez R., Simone O., De Santis V., Torres T. \& Ortiz J.E. (2013) - New data on the Pleistocene of Trani (Adriatic coast, southern Italy). Italian Journal of Geosciences, 132(2), 239253.

Caldara M., Mastronuzzi G., Palmentola G., Sansò P., Tuccimei P. \& Vesica P.L. (2003) - Reply to the comment by P.J. Hearty \& G. Dai Pra. Quat. Sc. Review, 22(4-6), 2369-2371.

Caputo R., Bianca M. \& D'Onofrio R. (2010) - Ionian marine terraces of southern Italy: Insights into the Quaternary tectonic evolution of the area. Tectonics, 29. https://doi.org/10.1029/2009TC002625

Carobene M. (1980) - Terrazzi Marini: eustatismo e neotettonica. Geografia Fisica e Dinamica Quaternaria, 3(2), 35-41.

Ciaranfi N., Pieri P. \& Ricchetti G. (1992) - Note alla carta geologica delle Murge e del Salento (Puglia centro-meridionale). Mem. Soc. Geol. It., 41(1988), 449-460.

Cinque A., Patacca E., Scandone P. \& Tozzi M. (1993) - Quaternary kinematic evolution of the southern Apennines. Relationship between surface geological features and deep lithospheric structures. Annali di. Geofisica, 36(2), 249-260.
Coyne M.K., Jones B. \& Derek F. (2007) - Highstands during Marine Isotope Stage 5: evidence from the Ironshore Formation of Grand Cayman, British West Indies. Quaternary Science Reviews, 26, 536-559.

D'Agostino N., Jackson J.A., Dramis F. \& Funiciello R. (2001) Interactions between mantle upwelling, drainage evolution and active normal faulting: an example from the central Apennines (Italy). Geophysical Journal International, 147, 475-479.

De Santis V. \& Caldara M. (2015) - The 5.5-4.5 kyr climatic transition as recorded by the sedimentation pattern of coastal deposits of Apulia region, southern Italy. Holocene, 25, 1313-1329.

De Santis V. \& Caldara M. (2016) - Evolution of an incised valley system in the southern Adriatic Sea (Apulian margin): an onshore-offshore correlation. Geological Journal 51(2), 263-284.

De Santis V., Caldara M. \& Pennetta L. (2014a) - The marine and alluvial terraces of Tavoliere di Puglia plain (southern Italy). Journal of Maps, 10(1), 114-125.

De Santis V., Caldara M., Torres T. \& Ortiz J.E. (2014b) - Two middle Pleistocene warm stages in the Terraced Deposits of the Apulia Region (southern Italy). Quaternary international, 332, 2-18.

De Santis V., Caldara M., Pennetta L., Torres T. \& Ortiz J.E. (2013) Unconformity Bounded Stratigraphic Units in an Italian alluvial plain area: recognising and dating. Journal of Sedimentary Research, 83, 96-114.

De Santis V., Caldara M., Torres T. \& Ortiz J.E. (2010) - Stratigraphic units of the Apulian Tavoliere Plain: chronology, correlation with marine isotope stages and implication regarding vertical movements. Sedimentary Geology, 228, 255-270.

De Santis V., Caldara M., Torres T., Ortiz J.E. \& Sánchez-Palencia Y. (2018) - A review of MIS 7 and MIS 5 terrace deposits along the gulf of Taranto based on new stratigraphic and chronological data. Italian Journal of Geosciences, 137, 349-368.

De Santis V., Caldara M., Pennetta, L. (2020a) - Continuous backstepping of Holocene coastal barrier systems into incised valleys: Insights from the Ofanto and Carapelle-Cervaro valleys. Water, 12(6), 1799

De Santis V., Caldara M. \& Pennetta L. (2020b) - Transgressive architecture of coastal barrier systems in the ofanto incised valley and its surrounding shelf in response to stepped sea-level rise. Geosciences, 10(12), 497.

De Santis V., Caldara M., Torres T., Ortiz J.E. \& Sánchez-Palencia Y. (2020c) - The role of beach ridges, spits, or barriers in understanding marine terraces processes on loose or semiconsolidated substrates: Insights from the givoni of the Gulf of Taranto (southern Italy). Geological Journal, 55(4), 2951-2975.

Doglioni C., Mongelli F. \& Pieri P. (1994) - The Puglia uplift (SE Italy): an anomaly in the foreland of the Apenninic subduction due to buckling of a thick continental lithosphere. Tectonics, 13(5), 1309-1321.

Doglioni C., Tropeano M., Mongelli F. \& Pieri P. (1996) - Middle-late Pleistocene uplift of Puglia: an anomaly in the Apenninic foreland. Memorie Società Geologica Italiana 51, 101-117.

Dutton A., Carlson A.E., Long A.J., Milne G.A., Clark P.U., DeConto R., Horton, B.P., Rahmstorf S., \& Raymo M.E. (2015) - Sea-level rise due to polar ice-sheet mass loss during past warm periods. Science, 349(6244), aaa4019. https://doi.org/10.1126/science. aaa4019.

Faccenna C., Becker T.W., Miller M.S., Serpelloni E., Willett S.D. (2014) - Isostasy, dynamic topography, and the elevation of the Apennines of Italy. Earth and Planetary Science Letters, 407, 163 174.

Faccenna C., Funiciello F., Civetta L., D’Antonio M., Moroni M. \& Piromallo C. (2007) - Slab disruption, mantle circulation and the opening of the Thyrrenian basin. Geological Society of America Special paper, 418, 153-169.

Faccenna C., Molin P., Orecchio B., Olivetti V., Bellier O., Funiciello F., Minelli L., Piromallo C., Billi A. (2011) - Topography of the Calabria subduction zone (southern Italy): Clues for the origin of Mt. Etna. Tectonics, 30(1), 1-20

Ferranti L., Antonioli F., Mauz B., Amorosi A., Dai Pra G., Mastronuzzi G., Monaco C., Orru P., Pappalardo M., Radtke U., Renda P. Romano P., Sansò P. \& Verrubbi V. (2006) - Markers of the last interglacial sea-level high stand along the coast of Italy: tectonic implications. Quaternary International, 145-146, 30-54. 
Grant K.M., Rohling E.J., Bar-Matthews M., Ayalon A., MedinaElizalde M., Ramsey C.B., Satow C. \& Roberts A.P. (2012) - Rapid coupling between ice volume and polar temperature over the past 150,000 years. Nature 491, 744-747. https://doi.org/10.1038/ nature 11593

Grant K.M., Rohling E.J, Ramsey C.B., Cheng H., Edwards R.L., Florindo F., Heslop D., Marra F., Roberts A.P., Tamisiea M.E. \& Williams F. (2014) - Sea-level variability over five glacial cycles. Nature Communications, 5, 5076.

Gravina M.F., Ardizzone G.D., Scaletta F. \& Chimenz C. (1989) Descriptive analysis and classification of benthic communities in some Mediterranean coastal lagoons (central Italy). Marine ecology, 10, 141-216.

Hearty P.J. \& Dai Pra G. (1992) - The age and stratigraphy of Middle Pleistocene and younger deposits along the Gulfof Taranto (Southeast Italy). Journal of Coastal Research, 8(4), 82-105.

Iannone A. \& Pieri P. (1979) - Considerazioni critiche sui tufi calcarei delle Murge. Nuovi dati litostratigrafi ci e paleoambientali. Geografia. Fisica e Dinamica Quaternaria, 2, 173-186.

Lajoie K.R. (1986) - Coastal tectonics. In: Active tectonics. National Academy Press, Washington D.C., 95-124.

Lavecchia G., Boncio P., Creati N. \& Brozzetti F. (2003) - Some aspects of the Italian geology not fitting with a subduction scenario. Journal of the Virtual Explorer, 10, 1-14.

Marra F., Bahain J.J., Jicha B.R., Nomade S., Palladino D.M., Pereira A., Tolomei C., Pierre Voinchet P., Anzidei M., Aureli D., Ceruleo P., Falgueres C., Florindo F., Gatta M., Ghaleb B., La Rosa M., Peretto C., Petronio C., Rocca R., Rolfo M.F., Salari L., Smedile A. \& Tombret O. (2019) - Reconstruction of the MIS 5.5, 5.3 and 5.1 coastal terraces in Latium (central Italy): A re-evaluation of the sea-level history in the Mediterranean Sea during the last interglacial. Quaternary International, 525, 54-77.

Mastronuzzi G., Caputo R., Bucci D., Fracassi U., Iurilli V., Milella M. Pignatelli C. Sansò P. \& Selleri G. (2011) - Middle-Late Pleistocene evolution of the Adriatic coastline of Southern Apulia (Italy) in response to relative sea-level changes. Geografia Fisica e Dinamica Quaternaria, 34(2), 207-221.

Mastronuzzi G., Quinif Y., Sansò P. \& Selleri G. (2007) - Middle-Late Pleistocene polycyclic evolution of a geologically stable coastal: area (southern Apulia, Italy). Geomorphology, 86, 393-408.

Mastronuzzi G. \& Sansò P. (Eds.) (2003) - Quaternary coastal morphology and sea level changes. Field Guide. Puglia 2003, Final Conference -Project IGCP 437 UNESCO - IUGS, Otranto/ Taranto - Puglia (Italy) 22- 28 September 2003, GI2S Coast Gruppo Informale di Studi Costieri, Research Publication, 5, 184 pp, Brizio srl, Taranto

Meschis M., Scicchitano G., Roberts GP., Robertson J., Barreca G., Monaco C., Spampinato C., Sahy D., Antonioli F., Mildon Z.K \& Scardino G. (2020) - Regional Deformation and Offshore Crustal Local Faulting as Combined Processes to Explain Uplif Through Time Constrained by Investigating Differentially Uplifted Late Quaternary Paleoshorelines: The Foreland Hyblean Plateau, SE Sicily. Tectonics, 39:e2020TC006187. https://doi. org/10.1029/2020TC006187

Moretti M. \& Tropeano M. (1996) - Strutture sedimentarie deformative nei depositi tirreniani di Bari. Mem. Soc. Geol. It, 51, 485-500.

Moretti M., Alfaro P. \& Owen G. (2016) - The environmental significance of soft-sediment deformation structures: key signatures for sedimentary and tectonic processes. Sedimentary Geology, 344, 1-4.

Murray-Wallace C.V. \& Woodroffe C.D. (2014) - Quaternary Sea-Level Changes: A Global Perspective. Cambridge University Press.

Negri A., Amorosi A., Antonioli F., Bertini A., Florindo F., Lurcock P.C., Marabini S., Mastronuzzi G., Regattieri E., Rossi V., Scarponi D. Taviani M., Zanchetta G. \& Vai G.B. (2015) - A potential global boundary stratotype section and point (GSSP) for the Tarentian Stage, Upper Pleistocene, from the Taranto area (Italy): Results and future perspectives. Quaternary International, 383, 145-157.

Ortiz J.E., Torres T., Julià R., Delgado A., Llamas F.J., Soler V. \& Delgado J. (2004) - Numerical dating algorithms of amino acid racemization ratios from continental ostracodes. Application to Guadix-Baza basin (southern Spain). Quaternary Science Reviews, 23(5-6), 717-730.

Patacca E. \& Scandone P. (2001) - Late thrust propagation and sedimentary response in the thrust belt-foredeep system of the Southern Apennines (Pliocene-Pleistocene). In: Vai G.B. \& Martini
I.P. (eds.), Anatomy of an Orogen: The Apennines and adjacent Mediterranean Basins. Kluwer Academic Publisher, 404-440.

Patacca E. \& Scandone P. (2004) - The Plio-Pleistocene thrust beltforedeep system in the Southern Apennines and Sicily (Italy). Special Volume Italian Geological Society for the IGC 32 Florence-2004, 93-129.

Pérès J.M. (1967) - The Mediterranean benthos. Oceanography Marine Biology Annual Review, 5, 449-553.

Pieri P. (1975) - Geologia della Città di Bari. Memorie della Società Geologica Italiana, 14, 379-407.

Pieri P., Sabato L., Spalluto L. \& Tropeano M. (2011) - Note Illustrative della Carta Geologica d'Italia alla scala 1:50.000, F. 438 Bari. 105 pp., LAC, Firenze.

Pirazzoli P.P.A. (2005) - Marine erosion features and bioconstructions as indicators of tectonic movements, with special attention to the eastern Mediterranean area. Z. Geomorph, 137, 71-77.

Quarta G., Fago P., Calcagnile L., Cipriano G., D’Elia M., Moretti M., Scardino G., Valenzano E. \& Mastronuzzi G. (2019) - 14C Age Offset in the Mar Piccolo Sea Basin in Taranto (Southern Italy) Estimated on Cerastoderma Glaucum (Poiret, 1789). Radiocarbon, 61, 1387-1401.

Ricchetti G., Ciaranfi N., Luperto Sinni E., Mongelli F. \& Pieri P (1992) - Geodinamica ed evoluzione sedimentaria e tettonica dell'avampaese apulo. Mem. Soc. Geol. It., 41(1988), 57-82.

Rovere A., Raymo M.E., Vacchi M., Lorscheid T., Stocchi P., GómezPujol L., Harris D.L., Casella E., O'Leary M.J. \& Hearty P.J. (2016) The analysis of Last Interglacial (MIS 5e) relative sea-level indicators: Reconstructing sea-level in a warmer world. EarthScience Reviews, 159, 404-427.

Salvador A. (1987) - Unconformity-bounded stratigraphic unit, Geological Society of American Bulletin, 98, 232-237.

Salvador A. (1994) - International Stratigraphic Guide. A Guide to stratigraphic classification, terminology, and procedure, The International Union of Geological Sciences and the Geological Society of America (eds.), pp. 214.

Sansò P., Margiotta S., Mastronuzzi G. \& Vitale A. (2015) - The geological heritage of salento leccese area (Apulia, southern Italy). Geoheritage, 7, 85-101.

Schellmann G. \& Radtke U. (2004) - A revised morpho- and chronostratigraphy of the Late and Middle Pleistocene coral reef terraces on Southern Barbados (West Indies). Earth-Science Reviews, 64, 157-187.

Schiattarella M., Giano S.I. \& Gioia D. (2017) - Long-term geomorphological evolution of the axial zone of the CampaniaLucania Apennine, Southern Italy: a review. Geologica Carpathica, 68(1), 57-67.

Servizio Geologico d'Italia (1968) - Carta Geologica d'Italia alla scala 1:100.000, 189 Altamura.

Servizio Geologico d'Italia (2003) - Carta geologica d'Italia - 1:50.000 Catalogo delle formazioni Fascicolo V - Unità validate. Quaderni del Servizio Geologico, serie III, 7(5), 210 pp.

Servizio Geologico d'Italia (2011) - Carta Geologica d'Italia alla scala 1:50.0000, 438 Bari. ISPRA, Roma.

Tropeano M., Sabato L. \& Pieri P. (2002) - Filling and cannibalization of a foredeep: the Bradanic Trough, Southern Italy. Geological Society, London, Special Publications 191, 55-79.

Vacchi M., Marriner N., Morhange C., Spada G., Fontana A. \& Rovere A. (2016) - Multiproxy assessment of Holocene relative sea-level changes in the western Mediterranean: Sea-level variability and improvements in the definition of the isostatic signal. EarthScience Reviews, 155, 172-197.

Valenzano E., Scardino G., Cipriano G., Fago, P., Capolongo D., De Giosa F., Lisco S., Mele D., Moretti M. \& Mastronuzzi G. (2018) - Holocene morpho-sedimentary evolution of the Mar Piccolo basin (Taranto, Southern Italy). Geografia Fisica e Dinamica Quaternaria, 41, 119-135

Westaway R. (1993) - Quaternary uplift of southern Italy. Journal of Geophysical Research, 98(B12), 741-772.

Zander A., Fülling A., Brückner H. \& Mastronuzzi G. (2006) - OSL dating of Upper Pleistocene littoral sediments: a contribution to the chronostratigraphy of raised marine terraces bordering the Gulf of Taranto, South Italy. Geografia Fisica e Dinamica Quaternaria, 29(1), 33-50. 